\title{
Siber Zorbalık Bağlamında Twitter Fenomenleri ${ }^{1}$ \\ Kenan BÖLÜKBAŞ \\ Dr.,TRT Müzik Kanal Koordinatörü \\ bolukbaskenan@gmail.com \\ Orcid ID: https://orcid.org/0000-0001-2345-6789
}

\author{
Ali Murat KIRIK \\ Doç. Dr., Marmara Üniversitesi, \\ İletişim Fakültesi, Radyo, Televizyon ve Sinema Bölümü \\ murat.kirik@marmara.edu.tr \\ Orcid ID: https://orcid.org/0000-0002-5771-4843
}

Öz

Yakın geçmişte iletişimin temel mecrasının geleneksel medyadan yeni medya denilen sosyal medya alanına yönelmesiyle alışılagelmiş bazı kavramlar farklı anlamlara bürünmüş̧ür. Bu kavramlardan biri de akran zorbalığıdır. Bu noktada teknolojinin "kötüye yorulması ve zarar verme amaçlı kullanılması" ile "siber (sanal) zorbalık" adı verilen yeni bir kavramı ortaya çıkmıştır. Siber zorbalık, sosyal medyada sıkça karşılaşılan bir olgudur. Yüksek takipçili hesaplara sahip olan Twitter fenomenleri de bazı takipçilerinin kendilerine ve diğer takipçilerine yönelttiği siber zorbalıkla mücadele etmek zorunda kalmaktadır.

Twitter fenomenlerinin siber zorbalıkla ilgili deneyim ve düşüncelerini ortaya koymayı amaçlayan bu çalışma, fenomenolojik nitel bir araştırma olarak tasarlanmıştır. Yüksek takipçili beş Twitter fenomeninden konu bağlamında görüş alınarak, siber zorbalık olgusu Twitter fenomenlerinin deneyimleri ve bakış açıları ile ele alınmaya çalışılmıştır. Araştırma bulguları, diğer sosyal medya kullanıcıları gibi Twitter fenomenlerinin de çeşitli siber zorbalık davranışlarına maruz kaldıklarını, farklı boyut ve düzeylerde bu davranışlardan etkilendiklerini ve söz konusu davranışlarla baş etmek için çeşitli stratejiler geliştirdiklerini ortaya koymaktadir.

\footnotetext{
${ }^{1}$ Makale Geliş/Kabul Tarihi: 07.07.2020 / 08.09.2020

Künye Bilgisi: Bölükbaş, K. Ve Kırık, A.M. (2020). Siber Zorbalık Bağlamında Twitter Fenomenleri. Kahramanmaraş Sütçü İmam Üniversitesi Sosyal Bilimler Dergisi, 17 (2), 944-966. DOI: $10.33437 / k s u s b d .764804$
} 


\title{
K. Bölükbas-A.M. Kırık Siber Zorbalık Bağlamında Twitter Fenomenleri
}

Anahtar Kelimeler: Akran zorbalığı, Siber Zorbalık, Sosyal Medya, Twitter Fenomenleri.

\section{Twitter Phenomena In The Context Of Cyberbullying}

\begin{abstract}
Within the context of the recent past, the perception and meaning of some conventional concepts have been changing as the new media becoming the main channel of inter-personal communication. Bullying or peer bullying is one of those concepts. A new concept meaning 'the misuse of the technology or using it as a tool to harm others' has been emerged from the above concept recently, which is called 'cyber bullying'. Nowadays, cyber bullying is one of the most common things that one can come across on social media. Twitteratis, who have famous accounts followed by so many users at Twitter, and some of their followers are also exposed to various types of cyber bullying behaviours. Thus, they feel obliged to struggle against this kind of behaviours.

Aiming to investigate the experiences and viewpoints of the Twitteratis on cyber bullying, the current study has designed as a qualitative phenomenological research. It employs a semi-structured interview schedule to examine five influential Twitteratis' experiences of and viewpoints on cyber bullying. The research findings reveal that alike all other social media users, the Twitteratis have been exposed to various types of cyber bullying and psychologically influenced. It has also found out that they have developed varied strategies to overcome the negative effects of the cyber bullying.
\end{abstract}

Keywords: Bullying, Cyber Bullying, Social Media, Twitteratis.

\section{Giriş}

Günümüzde bilgi ve iletişim teknolojilerinde yaşanan gelişmeler insan hayatı açısından önemli bir duruma gelmiştir. Bilişim dünyasındaki bu devinim; sosyal, kültürel, siyasal, ekonomik açıdan hayatımızı etkilemektedir. Bu etkilerin somut bir şekilde ortaya çıkmasında rol alan faktörlerin başında "internet" gelmektedir. Bu küresel etki ile her türlü bilgiye, bir önceki kuşaktan farklı olarak daha yoğun, daha hızlı ve interaktif bir şekilde ulaşan yeni bir kuşak ortaya çıkmıştır. Bu kuşak, internetin sağladığı imkânlarla zaman-mekân sınırsızlığında daha özgür bir yapıda söylemlerini dile getirmektedir. Farklı bir şekle bürünen yaşam 
pratikleri, dijital dünyaya daha yabancı olan önceki kuşakları da içine alarak sosyal ilişkileri farklı bir boyuta taşımaktadır. Bu yönleriyle, sözü edilen değişimlerin en fazla hissedildiği yerlerden birinin de iletişim mecrası olduğunu söylemek mümkündür.

İletişimin dijital etki ve sonuçlarının görüldüğü yerlerin başında, "sosyal medya" platformları gelmektedir. Gün geçtikçe kullanıcı sayısı artan sosyal medyada, çok kısa zaman aralıklarında yüzlerce gönderinin, tweetin, görselin ve videonun paylaşılmakta olduğu, paylaşımların beğeni ve yorumlarla geri dönütünün sağlandığı görülmektedir. Görselliğe ve anındalığa dayanan bu dijital yapı, artık yaşantımızın olmazsa olmazları arasındadır. Bugün bu dönüşüm, hayatımızın bir uzantısı olarak varlığını ve gelişimini sürdürmektedir. Bu süreç, sayısal verilerle de desteklenmektedir. Türkiye İstatistik Kurumu'nun 2019 y1lı verilerine göre, ülkemizde internet kullanan bireylerin oranı, \% 75,3 seviyesine ulaşmıştır (TÜiK, 2019). We Are Social 2020 raporuna göre ise Türkiye'de 62 milyon internet kullanıcısı bulunmaktadır. Rapora göre, 77 milyon mobil kullanıcı yer almaktadır. İstatistikler, sosyal medyanın yoğun bir şekilde kullanıldı̆̆ını göstermektedir. 54 milyon sosyal medya kullanıcısının varlığı bu durumu açık bir şekilde gözler önüne sermektedir (Dijilopedi.com, 2020). "Digital 2019 in Turkey" istatistiklerine göre, Türkiye'de masaüstü bilgisayar veya laptop kullananların oran $1 \% 48$, tablet kullananların oran $\% 25$ iken \%77'lik bir oran akıllı telefon kullanmaktadır. Türkiye'de, nüfusun \%72‘sine tekabül eden 59,3milyon internet kullanıcısının 56,3 milyonu internete telefonlarından erişim sağlamaktadır (Dijilopedi.com, 2019). $\mathrm{Bu}$ verilere göre bireylerin internet kullanımı artık "yerindelik" faktöründen kurtularak mobile indirgenmiştir. İnternetin cep telefonlarına kadar indirgenmesi; iletişim, bilgi, haber alma, eğlence amaçlarıyla kullanan sosyal medyanın popülerliğini artırmış, kullanımını daha aktif bir hale getirmiştir. "Hootsuite ve We Are Social" raporlarına göre Türkiye’nin sosyal medya kullanım düzeyi, dünya ortalamasının üstünde bir seyir göstermektedir (Dokuz8 Haber, 2019). “Digital 2020 - Global Digital Overview” raporuna göre Türkiye, Facebook kullanımında dünyada 10. iken Avrupa'da birinci sırada yer almaktadır. Insagram'da altıncı strayı alırken Twitter'da dünya genelinde altıncl, Avrupa'da ikinci sırada gelmektedir. En çok kullanılan sosyal medya platformlarl: YouTube, Instagram, Facebook, Twitter ve Linkedln şeklinde siralanmaktadır (Medya Akademi, 2020).

Gerek eğlence gerekse bilgiyi bir arada tutma imkanı sağlayan tüm bu sosyal medya platformları, karmaşık ve bir o kadar da kapsamlı bir yapıya sahiptir. Genel bir ifadeyle sosyal medya "dünya genelindeki bilgisayar ağlarını ve kurumsal bilgisayar sistemlerini birbirine bağlayan elektronik iletişim ağı olarak tanımlanan internetin gelişmesiyle bireyleri farklı bireylerle sanal uzamda buluşturan web tabanlı hizmetler" şeklinde ifade edilebilmektedir (Köseoğlu, 


\section{K. Bölükbas-A.M. Kırık Siber Zorbalık Bağlamında Twitter Fenomenleri}

2006: 152). Daha kapsamlı tanıma göre sosyal medya; "bireylerin sınırları belli olmayan bir sistem içerisinde açık ve yarı açık profil oluşturmalarına izin veren, farklı kişilerle bağlantı paylaşımında bulunan kişilerin listesini gösteren web tabanlı hizmetler" olarak tanımlanabilmektedir (Kuşay, 2010: 67).

Sosyal medya, iletişim çağının önemli fenomeni durumuna gelmiştir ve etkisini her geçen gün arttırmaktadır. İletişim alanında birçok değişikliğe neden olmuş ve sosyal yapı için devrim niteliğinde etkiler meydana getiren bu yapı, kullanıcıların istedikleri tüm içeriği paylaşabilmelerini sağlamıştır. Dünyanın geri kalanında olduğu gibi Türkiye'de de sosyal ağ sitelerinin sosyal ve politik amaçlarla kullanılması, sosyal medyanın gündem belirleme yeteneğini ön plana çıkarmıştır (Kırık, Çetinkaya ve Şahin, 2014: 49 - 52).

$\mathrm{Bu}$ doğrultuda sosyal medya, bireylerin karar verme sürecini de etkilemektedir. Örneğin, bazı yorumcular, sosyal medyanın "2011 Arap devrimleri ve isyanları” ile bütünleştiğine, ABD'deki seçimlerin sosyal medya tarafından kolaylaştırıldığına inanmaktadır. Bulmer ve Di Mauro'nun (2009) anketi, sosyal medyanın "karar verme" üzerindeki etkisini araştırmak için bir başlangıç noktasıdır. 20 ülkede, 97 örgütte, 105 katılımcıyla gerçekleştirilen bu araştırma, sosyal ağ katılımının şirketlerde yürütme kararını giderek daha fazla etkilediği sonucuna varmıştır. $\mathrm{Bu}$ durum sosyal medyanın karar verme aşamasındaki etkisini gözler önüne sermektedir. Sosyal medyada sürekli benzer mesajlara maruz kalmak, insanların bu mesajları "doğru" olarak kabul etmelerini kolaylaştırmaktadır. Burada önemli olan nokta, mesajların yanlış olduğu "bildiğinde" doğru gibi davranılmasıdır. Sosyal medya aracılığıyla sunulan içerikler noktasında, insanlar iddiaların geçerliliğini nadiren kontrol etmektedir. $\mathrm{Bu}$ durum karar verme sürecinin sosyal medya aracılığıyla hızlı bir şeklide işlendiğini gözler önüne sermektedir. Dolayısıyla sosyal medyanın "etkileşim" ve "paylaşım" unsurları, bireylerin kullanım amaçları ve şekilleri bu noktada belirleyici olmaktadır. Bireylerin karşılaştıkları içeriklere tepkileri, sosyal medyada sergiledikleri davranış eğilimlerini ortaya çıkarmaktadır. Bu eğilimler, sosyal medyanın çoklu/ çok sesli yapısı ile şekillenmektedir. Bu çok sesli yapı, davranışlara olumlu yansıyabileceği gibi olumsuzluk ya da anlaşmazlık şeklinde de açığa çıkabilmektedir.

Örneğin, siyasi bilgi kaynakları, sosyal medyayı haber için kullananların siyasi anlaşmazlığa maruz kaldıklarını göstermektedir. Hem "anket kanıtı" hem de "büyük veri" analizi, sosyal medya ile insanların siyasi yelpazenin her iki tarafından gelen haberlere maruz kaldığını ve bunun sonucunda sosyal medya kullanıcılarının normalden daha geniş bir dizi hikâye ile karşılaştıklarını göstermektedir. Bu noktada sosyal medya kullanıcıları daha fazla ağa kolay bir şeklide erişim sağlama eğiliminde olmaktadır. Böylece kullanıcılar, daha geniş bir görüş yelpazesine maruz kalmaktadır. Ampirik kanıtlar, haber kullanımının 
ve siyasi anlaşmazlıklara maruz kalmanın sosyal medyada yoğun olduğunu göstermektedir. Daha spesifik olarak, anlaşmazlığın insanları kamusal alanda karşılaştıkları çeşitli bilgilere karşı daha kararsız ve dolayısıyla daha açı hale getirdiğini göstermektedir (Gil de Zúñiga, Barnidge ve Diehl, 2018: 304).

Facebook ve Twitter gibi sosyal medya platformları, seçimlerde siyasi adayı tanıtmak, oy potansiyellerini etkilemek ve bireyleri siyasi ideolojilerine göre gruplandırmak ve ikna etmek için giderek daha fazla kullanılmaktadır. Bu noktada sosyal medyanın politika üzerindeki etkisi, kurumların ve kampanyaların mesajlarını birden fazla ağa yaymak için ödeme yaptığı ücretli politik reklamlar aracılığıyla karşımıza çıkmaktadır. Kampanyalar, incelikle hazırlanmış mesajların kullanılması sırasında hedefli reklamcılık için kullanıcı verilerinin satılması veya satın alınması gibi tekniklere başvurabilmektedir. Bu "mikro" hedefli reklamlar genellikle sahte haberlerin veya yanlış bilgilerin bulunduğu yerdir. Twitter ve Facebook bu noktada, 2016 - ABD başkanlık seçimlerinin sonucunu etkilemek yani "toplumsal ikna" için Rus operatörler tarafindan platformlarının kullanıldığını açıklamıştır.

Toplumsal ikna, kurumlar tarafından sosyal medya aralığı ile yapılabileceği gibi bireysel bazda da karşımıza çıkabilmektedir. Bu noktada toplumda "fenomen" olarak nitelendirilen bireyler devreye girmektedir. Fenomenler "karar verme" aşamalarında etkileme potansiyelleri ile karşımıza çıkmaktadır. Fenomenlerin bu potansiyeli, her yaştan her kesimden bireyi yönlendirebilme gücüne sahip olabilmektedir. Sosyal medyada, düşünce liderleri ve alan uzmanları daha fazla otoriteye sahip olmakla birlikte, ikna edicilikleri ile de ön plana çıkmaktadır. Özellikle sosyal medya fenomenlerini günümüz dünyasının "kanaat önderleri" şeklinde nitelendirmek mümkündür. İster sportif ister politik isterse çevresel bir etkinlik olsun, sosyal medya kullanıcıları haber ve analiz için uygun otoriteye veya ne yapılacağına dair talimatlara bakmaktadır. Bu noktada kimi zaman fikirsel çatışmalar ortaya çıkabilmektedir. Nitekim dijitalleşmenin ve popülaritenin etkileriyle gün geçtikçe kullanımı artan sosyal medya mecralarında "yaşanılan değil yaşanılması hayal edilen", "siber", "idealize edilmiş", "mükemmelleştirilmiş bir kimlik" ile "gerçeklik yerine görüntülerin önem taşıdığı bir dünya" ortaya çıkmaktadır (İsmayılzada, 2017: 227). Oluşan bu sanal kimlikler, bireylerin dijital mecrayı kötü amaçlarla kullanmalarına önayak olmaktadır. Sosyal medyanın, kimlik dönüşümüne uğrayan kullanıcılar tarafından, toplumsal değerler gözetilmeksizin kullanılması sevinmek, üzülmek, zorbalık gibi davranışların sosyal medyada kendine yeni bir ifade alanı bulmasına neden olmuştur. Sosyal medyadaki bu dönüşüm, kullanıcıların kendilerine sanal bir deri giydirmesi olarak tanımlanmıştır (Bailey, 2001: 335-336'dan aktaran Ismayılzada, 2017: 230). Bu durum, "siber zorbalı" kavramını ortaya çıkarmıştır. 


\section{K. Bölükbas-A.M. Kırık Siber Zorbalık Bağlamında Twitter Fenomenleri}

Siber zorbalık kavramına yönelik farklı tanımlamalar mevcuttur. Genel bir ifadeyle, zarar verici ve tehdit edici iletilerin online mesaj ya da e-posta aracılığıla gönderilmesi sonucu, birisi hakkında hoş olmayan yorumların online ortamda veya sosyal paylaşım ağlarında yapılması siber zorbalık olarak ifade edilmektedir (Hinduja ve Patchin, 2010).Bilgi ve iletişim teknolojilerini kullanarak bir birey ya da gruba, özel ya da tüzel bir kişiliğe karşı yapılan teknik ya da ilişkisel tarzda zarar verme davranışlarının tümü de siber zorbalık olarak tanımlanmaktadır Siber zorbalık literatürde, tekno zorbalık, elektronik zorbalık, çevrimiçi zorbalık gibi kavramlarla ifade edilmektedir (Çelik ve Tekin, 2015: 344). Siber zorbalığ gerçekleştiren bireylere siber zorba, siber zorbalığa maruz kalan bireylere ise siber mağdur ya da siber kurban adı verilmektedir. Bir eylemin "siber zorbalık" olarak adlandırılabilmesi için bazı kıstasları sağlaması gerekmektedir. Bunlardan birincisi, siber zorbanın, mağdura karşı düşmanca hisler taşıması ve bireye zarar vermeyi hedeflemesidir. İkincisi, siber zorba tarafından gerçekleştirilen olayın, mağdur tarafından zarar verici bir biçimde görülüyor olması zorunluluğudur. Yani zorbalığa uğramış mağdurun bu durumu negatif bir deneyim olarak kodlaması gerekmektedir. Güç dağılımının dengesiz olarak nitelendirilen bir ilişki içerisinde gerçekleşmesiyle ortaya çıkan olayda bir diğer kıstas ise, olumsuz online hareketlerin sürekli görülüyor olması durumudur. Bu kıstasları "israr edicilik", "tekrar etme" ve "zarar verme" olarak özetlemek mümkündür(Serin, 2012: 22; Vandebosch and Van Cleemput, 2008). Burada dikkat edilmesi gereken bir nokta vardır. Tekrarlama kriterinde, siber zorbalık için farklı bir durum söz konusudur. Zorbalığa maruz kalan siber mağdurun yaşadığı psikolojik etkiler, zaman ve mekândan ayrı olarak yinelenebilmekte ve tekrar edebilmektedir. Bu durum siber zorbalığın süregelen bir süreç izlediğini ve etkilerinin devam edebileceğini göstermektedir. Tüm bu özellikler farklı şekillerde karşımıza çıkabilmektedir. Bu noktada siber zorbalık çeşitleri devreye girmektedir.

Siber zorbalığın iki çeşidi vardır: İlki olayın daha çok teknik yönünü içeren elektronik zorbalık, diğeri ise olayın daha çok psikolojik yönünü içeren elektronik iletişim zorbalı̆̆ıdır. Elektronik zorbalık kişilerin şifrelerini ele geçirmek, web sitelerini hacklemek, spam içeren/ bulaşıcı mailler göndermek gibi teknik olayları içermektedir. Elektronik zorbalık, bireysel yapılabileceği gibi birçok kişi tarafindan organize bir şekilde aynı anda da yapılabilmektedir. Bu saldırılar donanım ve yazılımlara direkt olarak etkide bulunurken, dolaylı olarak kişilerin duygularına da etki etmektedir. E-iletişim zorbalığı ise bilgi ve iletişim teknolojilerini kullanarak kişileri sürekli rahatsız etme, kişilerle alay etme, isim takma, dedikodu yayma, internet üzerinden kişiye hakaret etme ya da kişinin rızası olmadan fotoğraflarını yayınlama gibi ilişkisel saldırı davranışlarını içermektedir. Bu da direkt olarak duyguları etkilemektedir (MEB, t.y.:1). Dolayısıyla küresel anlamda zaman - mekân gözetmemesi ve uzun süreli etkileri bakımından siber zorbalığın, evrensel bir sorun niteliğinde olduğunu söylemek 
mümkündür. Yapılan çalışmalar incelendiğinde, siber zorbalığın temelinde birçok nedenin olduğu görülmektedir. Sosyal medya hesaplarının ele geçirilmesi, şifrelerin kırılması ve o hesaplardan kişiyi zor durumda bırakacak paylaşımların yapılması, aşağılama, küfür, hakaret, tehdit, dışlama bu nedenler arasındadır. Siber zorbalığın meydana getirdiği olumsuz etkilere maruz kalan siber mağdur ise birçok "sosyal", "duygusal", "akademik" etkilerle karşı karşıya kalabilmektedir. Hayal kırıklığı, yalnızlık, özgüven eksikliği, kaygı, dışlanma çaresizlik, depresyon; zorbalığa uğrama sonucu açığa çıkan psikolojik, sosyal ve duygusal sorunlardandır. Siber zorbalık eğitim alanında ise özellikle ergen olarak nitelendirilen kuşağın karşısına devamsızlık ve notlardaki düşüş gibi olumsuz etkilerle çıkabilmektedir (Kılıçer, Özeke ve Çoklar, 2018:22; Taştekin ve Bayhan, 2018:23; Serin, 2012: 32). Willard (2007); siber zorbalığa maruz kalan kişilerin özellikle de çocukların zorbalık deneyimlerini ebeveynleri ya da yetişkinlerle paylaşmaktan kaçındıklarını belirtmektedir. Ayrıca bu durumdan haberdar olan ailelerinin, zorbalığa maruz kaldıklarından dolayı kendilerini suçlayabilecekleri, hatta cezalandırılabileceklerini düşünmektedir. Fakat tüm bu psikolojik etkiler, çeşitli parametreler gözönünde bulundurulduğunda değişim göstermektedir. Siber zorbalık etkileri yaş, cinsiyet, karakter ve buna bağlı olarak internet kullanım sıklığı gibi değişkenlerle farklı anlamlar yüklenebilmektedir (Aksaray, 2011: 415; Çelik ve Tekin, 2015; Erbaş ve Şahin Perçin, 2017: 178; Erdur - Baker, 2013: 286; Özdemir ve Akar, 2011: 621; Özer Baltac1, 2016: 56; Peker, Eroğlu ve Ada: 199; Tuncer ve Dikmen, 2016; Yiğit ve Seferoğlu, 2017: 21). Buna göre siber zorbalığa etki eden değişkenleri şu şekilde sıralamak mümkündür:

Cinsiyet: Siber zorbalığa etki eden değişkenlerin başında cinsiyet kavramı gelmektedir. Cinsiyet, sosyolojik boyutu olan bir değişken olarak karşımıza çıkmakta ve toplumun sosyo - kültürel yapısına göre şekil kazanmaktadır. Bu bağlamda siber zorbalığa mağdur ya da zorba olarak katılmada cinsiyet etkenini inceleyen araştırma bulguları birbirleriyle çelişkilidir (Aksaray, 2011: 415). Siber zorbalıkla ilgili çalışmaların büyük bir kısmı erkeklerin kadınlara göre daha sık bir biçimde siber zorbalık davranışlarında bulunduğunu, kadınların daha çok siber mağdur konumunda olduğunu göstermektedir. $\mathrm{Bu}$ görüşün tersini savunan çalışmaların yanı sıra cinsiyetin siber zorbalık üzerinde etkisinin olmadı̆̆ 1 bulgusuna ulaşan çalışmalar da mevcuttur (Yiğit ve Seferoğlu, 2017: 21). Ancak bu sonuca dayanarak erkeklerin her koşulda kadınlara göre daha fazla zorba olduklarını öne sürmek, yerinde bir saptama olmamaktadır (Özdemir ve Akar, 2011: 621).Siber zorbalığın sınırı yaşa bağlı değildir. İlkokuldan ergenliğe, ergenlikten yetişkinliğe kadar her yaş grubundaki birey siber zorba ya da siber mağdur olabilmektedir. Fakat hem erkeklerin hem de kızların siber zorbalığı 1617 yaşlarına kadar artarak devam etmekteyken, sonrasında ise her iki cinsiyet için de siber zorbalık yapma oranlarının düştüğü görülmektedir. Bu sonucun ortaya 


\section{K. Bölükbas-A.M. Kırık Siber Zorbalık Bağlamında Twitter Fenomenleri}

çıkmasında bu yaş gruplarının teknoloji ile ilintili olmaları, interneti ve sosyal ağları yoğun olarak kullanmaları etkili olabilmektedir (Erdur - Baker, 2013: 286).

\section{Gizlilik Hissi}

Günümüzde sosyal medya kullanıcıları, sosyal medya uygulamalarında kendi kimliklerinin dışında bir profil çizebilmektedir. Bu durum sonucunda bireyler arası etkileşim sürecinde "anon" olarak nitelendirilen, kimliği tamamen gizli kişiye dönüşebilmek mümkündür (Çelik ve Tekin, 2015). Böylece kötü niyetli kişiler gizli kimlikleri ile cesaret kazanmaktadır. $\mathrm{Bu}$ durum oluşan gizlilik hissinin, siber zorbalığı arttıran bir unsur olduğunu göstermektedir.

\section{Geleneksel Zorbalık}

Zorbalığın geleneksel boyutunu ifade eden akran zorbalığ1 ile teknolojik boyutunu ifade eden siber zorbalık arasında teknik farklılıklara rağmen benzerlikler de bulunmaktadır. Geleneksel akran zorbalığı, kendini savunamayacak kadar zayıf ve güçsüz ya da psikolojik olarak savunmasız olan mağdur üzerinde tekrarlayan fiziksel, sözel, psikolojik ataklar veya tehditler olarak tanımlanmaktadır (Olweus 1992, 1993a, 1994'den aktaran Aksaray, 2011: 408). Siber zorbalık, geleneksel zorbalığın birebir olan sözlü ve fiziksel etkilerini sanal ortama taşımaktadır. Yöntem özelliği dışında gerek zorbanın zarar verme amacı gerekse siber mağdurun uğradığı psikolojik baskılar nedeniyle benzerlik göstermektedir. Dolayısıyla geleneksel zorbalık, siber zorba olmada belirleyici bir etken olmaktadır. Yapılan araştırmalar, geleneksel zorbaların siber zorba olma olasılıklarının 4,6 kat daha fazla olduğunu ortaya çıkarmıştır (Yiğit ve Seferoğlu, 2017: 22 -23).

\section{İnternet Kullanım Sıklığı}

İnternet kullanım sıklığı siber zorbalığı etkileyen en önemli unsurlardan biridir. Sosyal medyanın mobil boyuta kadar indirgenmesiyle internet kullanımı artmıştır. Bu durum siber zorbalık gibi istenmeyen faktörlerin uygulama alanı kolaylaşmıştır. Yapılan araştırmalar, günlük ortalama interneti kullanım süresi 510 saat ve 11-16 saat olan bireylerin, 5 saatten daha az kullananlara göre daha fazla siber zorba oldukları sonucunu açığa çıkarmıştır (Tuncer ve Dikmen, 2016). Burada internet ve bilgisayarı sık kullanmanın yanı sıra riskli kullanmanın da siber zorbalığ 1 arttıran bir etken olduğu göz ardı edilmemelidir (Erdur Baker, 2013: 287).

\section{Ahlaki Çözülme}

Ahlaki çözülme, siber zorbaların "neden zorbalık yaptıklarını" kendi bakış açılarına göre yorumladıkları bir kavramdır. Bireyler yapacakları davranışların 
doğru olmadığını bilmelerine rağmen, bu davranışı kendi içlerinde belirli bir mantık çerçevesinde rasyonelleştirerek sürdürme eğiliminde olabilir (Bandura, 1999: 194'den aktaran Erbaş ve Şahin Perçin, 2017: 178). Buna göre siber zorbalık yapan bireyler kendilerini haklı gösterecek bir neden arayışına girmektedir. Bu durum siber zorbalığı artırıcı bir unsur olmaktadır.

\section{Empati}

Empati, siber zorbalığı etkileyen sosyolojik boyutlu değişkenlerden biridir. Empati ile siber zorba kendini siber mağdur yerine koyarak psikolojik ve davranışsal açıdan farkındalık kazanmaktadır. Buna göre empati, bir başkasının duygularını, içinde bulunduğu durumu, davranış ve hareketleri ile oluşan motivasyonunu anlayabilmek, anlamanın yanında bir de bunu içselleştirme süreci olarak da tanımlanabilmektedir (Özer Baltacı, 2016: 56). Yapılan çalışmalar incelendiğinde, empatik eğilim ile siber zorbalık arasında ters orantı olduğu görülmektedir. Buna göre empatik eğilim düştükçe siber zorbalığın arttığ gözlenmiştir. Dolayısıyla empatik eğilimin yüksek olması, bireyleri siber zorbalığa maruz kalmaktan korumaktadır (Peker, Eroğlu ve Ada, 2012: 199).Tüm bu değişkenlerin yanı sıra; bireylerin aile ilişkileri, aileden - çevreden aldığ 1 sosyal destek gibi etkenler de siber zorbalık için önemli unsurlardır. Buna göre ebeveynler ile olan ilişkilerin sağlıklı yürütülmesi ve bireye yönelik sosyal desteğin artırılması, siber zorbalığı azaltabileceği gibi bireyin toplum içinde yapıcı bir unsur olarak var olmasını da sağlayabilecektir.

Tüm bu parametreler göz önüne alındığında evrensel bir nitelik taşıyan siber zorbalığın, sosyal medya kullanıcıları açısından olumsuz etkilerinin değerlendirilmesi ve anlamlandırılması gerekmektedir. Bu noktadan hareketle bu araştırmada sosyal medyanın siber etkilerinin ortaya konulması için sosyal medya platformlarından biri olan Twitter mecrası ve bu mecranın fenomenleri üzerine bir analiz yapılmaktadır. Böylece "Siber Zorbalık Kavramı Bağlamında Twitter Fenomenleri” araştırmanın problem cümlesini oluşturmaktadır.

Günümüzde bireylerin zamanlarının büyük bir bölümünü geçirdikleri sosyal medya denilen dijital alanlar, birçok sosyal ağ platformunu içinde barındırmaktadır. Bu platformlardan biri de toplum nezdinde önemli bir yere sahip olan Twitter'dır. Twitter, kendi gündemini kendi kullanıcılarıyla oluşturabilen bir mecra konumundadır ve sahip olduğu anındalık - etkileşim sayesinde kullanıcılarına, kendi oluşturdukları içerikleri aktarabilme ya da diğer kaynaklardan gelen iletileri yeniden paylaşıma sokabilme, yorumlayabilme imkânı tanımaktadır (Dumanlı Kürkçü, 2017: 57-58).Sosyal medyayı oldukça aktif kullanan kullanıcılar, zaman içerisinde toplum tarafindan benimsenerek "kanaat önderi" ya da "fenomen" gibi kavramlarla nitelendirilmektedir. Bu bağlamda insanların davranış biçimini etkileyen ya da değiştiren kişiler, sosyal 


\section{K. Bölükbas-A.M. Kırık Siber Zorbalık Bağlamında Twitter Fenomenleri}

medya mecralarında hatırlı kişiler, ünlüler ya da ününü sadece sosyal medya üzerinde kazanmış kişiler, paylaşımları anında ve düzenli olarak izlenen, takipçi sayısı fazla olan kişiler "fenomen" olarak adlandırılmaktadır (Yaylagül, 2017: 222-223). Fenomenler, paylaşımlarının içerikleriyle toplumda bir bakıma "kanaat önderi” vazifesi yüklenmektedir. Dolayısıyla kanaat önderi bilgi ve mesajı kendi yorumu ile ilettikten sonra toplum üzerinde yeni bir bakış açısı sunmakta ve ciddi bir yönlendirmeye sebep olmaktadır. Bu durum, paylaşıma açık, yorumlayıcı ve tepkici bir sistemin oluşmasına zemin hazırlamaktadır (Sabuncuoğlu ve Gülay, 2014: 4).Oluşan bu tepkilerse, zaman zaman siber saldırı boyutuna taşınmakta ve siber zorbalığın önünü açmaktadır.

\section{Çalışmanın Amacı}

$\mathrm{Bu}$ çalışma, toplumun bütün kesimini etkileme potansiyeline sahip siber zorbalığın, sosyal medyada fenomen olarak tabir edilen bireyleri nasıl etkilediğini ortaya koymayı amaçlamaktadır. Bu amaç doğrultusunda aşağıdaki araştırma sorularına cevap aranmıştır:

1. Katılımcılar, Twitter fenomenliğini nasıl değerlendirmektedir?

2. Katılımcılar, elektronik zorbalığa maruz kalmakta mıdır?

3. Katılımcılar, elektronik içerik zorbalığına maruz kalmakta mıdır?

4. Katılımcılar, en çok hangi konularda siber zorbalığa maruz kalmaktadır?

5. Katılımcılar, elektronik içerik zorbalığının hangi türleri ile karşılaşmaktadır?

6. Siber mağdurların karşılaştıkları siber zorbalığa tepkileri, davranışları, etkilenme eşikleri ve seviyeleri nasıl şekillenmektedir?

7. Katılımcılar, siber zorbalıkla ilgili yasal süreçler hakkında bilgi sahibi midir?

8. Katılımcılar, karşılaş̦tıları siber zorbalıklar için yasal süreçlere başvurmakta midır?

\section{Yöntem}

Bir nitel fenomenoloji araştırması olarak tasarlanan bu çalışmada, Twitter fenomenlerinin siber zorbalıkla ilgili deneyim ve düşünceleri onların bakış açısından ele alınmıştır. Fenomenoloji araştırmaları, bir veya daha fazla kişinin belirli bir olgu hakkındaki deneyim ve düşüncelerini anlama ve açıklamaya odaklanır (Sart, 2015). Fenomenoloji araştırmalarındaki en önemli unsur, 
bireylerin ele alınan olgu veya olguları nasıl anlamlandırdıklarının onların bakış açısına göre ortaya konulmaya çalışılmasıdır (Patton, 2014). Bu araştırmada incelenen temel olgu siber zorbalıktır. Siber zorbalık olgusunun araştırma katılımcıları tarafindan nasıl deneyimlendiği, algılandığı ve anlaşıldığ 1 ortaya konulmaya çalışılmıştır. Buna ilave olarak katılımcıların Twitter fenomenliği algısı da temel düzeyde ele alınmıştır.

Bu bağlamda, her biri farklı mesleklere sahip olmakla birlikte Twitter'da sahip oldukları takipçi sayısı ve etkileyicilik potansiyeli itibarıyla birer fenomen olarak nitelendirilebilecek beş kişi bu araştırmanın çalışma grubu olarak belirlenmiştir. Çalışma grubunda yer alan Twitter fenomenlerinin tamamı erkek olup orta yaş grubuna (30-50 yaş aras1) mensuplardır. Katılımcılardan ikisi medya sektöründe çalışmakta olup biri televizyon yayıncılığ 1 ve spor muhabirliği, diğeri ise sosyal medya danışmanlığı yapmaktadır. Diğer üç katılımcı ise farklı alanlarda faaliyet gösteren özel sektör firmalarında çeşitli seviyelerde yöneticilik yapmaktadır. Bütün katılımcılar, uzun süreli sosyal medya deneyimine sahip olup Twitter'daki geçmişleri, 8 ila 12 yıl arasında değişmektedir. Araştırma etiği gereğince katılımcıların gerçek kimlikleri gizli tutulmuş ve her bir katılımcıya bir takma isim verilmiştir.

Araştırma verileri, araştırmacı tarafından geliştirilen bir yarı-yapılandırılmış görüşme formu aracılığıyla toplanmıştır. Beş ana soru ve çeşitli yardımcı sorulardan oluşan görüşme formu katılımcıların Twitter kullanma deneyimlerini, Twitter'da yaşadıkları siber zorbalık davranışlarını ve bu süreçlerle ilgili duygu ve düşüncelerini ortaya çıkarmaya yönelik olarak hazırlanmıştır. Görüşmelerin ikisi katılımcılarla yüz yüze, geri kalanlar ise internet üzerinden bir sesli ve görüntülü iletişim programı kullanılarak gerçekleştirilmiştir. Katılımcıların izni dâhilinde bütün görüşmeler kayıt altına alınmış ve akabinde bu kayıtlar kâğıda dökülerek analize hazırlanmıştır.

Analiz süreci, mülakat verilerinin tematik olarak kodlanmasıyla başlamış; kodlardan çeşitli kategorilere ve temalara ulaşılmıştır. Analiz sonuçlarından elde edilen bulgular ifade edilirken görüşme verilerinden doğrudan alıntılar yapmak suretiyle söz konusu bulguların desteklenmesi yoluna gidilmiştir. Yapılan analizlerin ve elde edilen bulguların geçerliliğini sağlamak amacıyla veriler ikinci bir araştırmacı tarafindan kodlanmış ve her iki araştırmacı tarafından yapılan kodlamalar karşılaştırılmıştır. Bu karşılaştırmalar, her iki araştırmacının yaptığ 1 kodlama ve analizlerin büyük ölçüde (yaklaşık \%80) örtüştügünü göstermektedir.

\section{Bulgular ve Yorum}

Çalışmada öncelikle, "sosyal medya fenomenliği”" ve özellikle de "Twitter fenomenliği”" kavramlarının katılımcılar için hangi anlamları ifade ettiği ele alınmıştır. Devamında ise siber zorbalığın iki türü olan elektronik ve elektronik 


\section{K. Bölükbas-A.M. Kırık Siber Zorbalık Bağlamında Twitter Fenomenleri}

içerik zorbalığı ve zorbalık davranışlarının maruz kalan kişilere etkileri ile bunlara gösterilen tepkiler ele alınmıştır.

\section{Twitter Fenomeni}

$\mathrm{Bu}$ çalışmanın önceki kısımlarında ele alındığı üzere genelde sosyal medya özelde ise Twitter fenomenliği kavramları, ilgili mecralarda oldukça rağbet gören bir hesaba sahip olmak, bu hesabın çok sayıda kullanıcı tarafından takip ediliyor olması ve ilgili kuruluş tarafından onaylanmış yani ilgili kişiye tahsis edilmiş olduğuna dair bir simgeyle (mavi renkte bir $\sqrt{ }$ ) işaretlenmiş olması anlamında kullanılmaktadır.

Çalışma kapsamında elde edilen verilerin incelenmesi ise her biri Twitter'da tanınırlık kazanmış bir veya daha fazla hesaba sahip olan ve kendi beyanlarına göre bu hesapları 18.000 ila 5.000.000 arasında değişen çok sayıda kişi tarafindan takip edilen katılımcıların, Twitter fenomenliği kavramına yukarıdaki standart anlamı yüklemedikleri görülmektedir. Bunun sebebi ise sosyal medyada takipçi sayısının göreceli bir durum olması, çeşitli dijital medya şirketlerinin para karşılı̆̆ında takipçi hareketliliği sağlaması, Twitter hesaplarının onaylanmasıyla ilgili süreçlerin görece değişken ve çeşitli dış etkenler tarafindan yönlendirmeye açık olması gibi durumlardır. Görüşülen fenomenlerden biri, sahip olduğu Twitter hesabının yaklaşık 300.000 kişi tarafından takip edildiğini ve aynı zamanda bir hayli etkili bir hesap olmasına rağmen belirli gruplar tarafından kendisi ve hesabıyla ilgili olarak Twitter'a yapılan müteaddit şikâyetler dolayısıyla hesabının bir türlü onay alamadığını belirtmiştir.

$\mathrm{Bu}$ bağlamda katılımcıların ortaya koyduğu Twitter fenomeni alg1 ve kavramı: "Gündemdeki çeşitli haber, olay, olgu, durum, fikir ve gelişmelerle ilgili olarak kendi gözlemlerini, düşüncelerini, duygularını, mizah anlayışlarını kullanarak oluşturdukları sözlü, yazılı ve görsel içerikleri takipçileri ve diğer Twitter kullanıcılarıyla paylaşmak suretiyle onların dikkatlerini çeken, beğenilerini kazanan, eğlendiren, onlara yeni fikirler veren ve belki de onlara rol modeller oluşturarak ufuklarını açan dijital aktörler" olarak tanımlanabilmektedir. İçeriği, kendi görüşlerini dile getirmek suretiyle bu araştırmaya katkı sağlayan katılımcılara ait olan bu tanım, Twitter fenomenliğinin çok sayıda kişi veya hesap tarafından takip edilen biri olma yaklaşımından, hazırlayıp sundukları içerikler aracılığıyla sosyal medyayı ve özellikle de Twitter'1 kullananları etkileyerek yönlendiren "kanaat önderi" veya "etkileyici bir rol” olmaya yönelik bir dönüşümü ifade etmektedir.

\section{Elektronik Zorbalık}

Araştırmada ikinci olarak katılımcıların siber zorbalıkla ilgili ne tür deneyimler yaşadığı belirlenmeye çalışılmıştır. Bu çerçevede öncelikle Twitter 
fenomenlerinin elektronik zorbalığa maruz kalıp kalmadıkları incelenmiştir. Bu bağlamda katılımcılardan yalnızca birinin sosyal medya hesaplarıyla ilgili elektronik zorbalığa maruz kaldığ 1 saptanmıştır. Birden fazla Twitter hesabı kullandığını beyan eden bu katılımcının hesaplarından biri başkaları tarafından ele geçirilmiş ve kendisine bir daha iade edilmemiştir. İlgili Twitter fenomeni de onaylı olmayan söz konusu hesabı geri almak için herhangi bir yasal girişimde bulunmadığını belirtmiştir. Bir başka katılımcı ise;

“... Çok uğraşıyorlar bununla ilgili bana devamlı uyarı e - mailleri geliyor. Buradan siz mi girmeye çalıştınız. Şuradan hesabınıza girilmeye çalışıldı. Kayseri'den sizin hesabınıza giriş yapılmaya çalışıldı gibi. Artık teknoloji de çok gelişti. Direkt görebiliyorlar IP'leri. Bu tip şeyler de çok başıma geldi... (Galip)

ifadeleriyle Twitter hesabına yönelik çeşitli elektronik zorbalık girişimleri yaşadığını; ancak şimdiye kadar bunların hiç birinin başarılı olmadığını dile getirmiştir. Bu bulgulardan yola çıkarak sosyal medyada ve özellikle Twitter'da elektronik zorbalığın yaygın olarak rastlanan bir durum olmadığı sonucuna ulaşmak mümkündür.

\section{Elektronik İçerik Zorbalığı}

Araştırma bulgularına göre katılımcıların sıklıkla maruz kaldığ 1 siber zorbalık türü, elektronik içerik zorbalığıdır. Görüşülen Twitter fenomenlerinin her biri farklı kapsamlarda ve çeşitli seviyelerde elektronik içerik zorbalığına maruz kaldıklarını dile getirmişlerdir. Bu aşamada özellikle şu yargıyı ifade etmenin faydalı olacağını söylemek mümkündür: "Bilgisayarların, akıllı cihazların ve internet kullanımının giderek yaygınlaştığı ve hayatın neredeyse her alanına girdiği günümüzde zorbalık olarak tanımlanan eylemler, siber veya siber olmayan şeklinde birbirlerinden ayırt edilemeyecek bir mahiyet kazanmaktadır." Ancak burada özellikle bir sosyal medya mecrası olan Twitter'da ortaya çıkan zorbalık davranışlarına odaklanıldığından siber zorbalık ve elektronik içerik zorbalığ kavramlarının kullanılması uygun bulunmuştur.

Twitter fenomenleri, maruz kaldıkları elektronik içerik zorbalığının çeşitli bağlamlarda ve farklı biçimlerde ortaya çıktığını belirtmiştir. Bütün katılımcılar, siber zorbalık olarak nitelendirilebilecek tepki ve davranışların özellikle gündemdeki spor ve siyaset konularına dair paylaşımlarına karşıllk olarak ortaya çıktığını ifade etmiştir.

Türkiye'de insanların konuştuğu konuların başında spor, özellikle de futbol ve siyaset geldiği bilinmektedir. Dolayısıyla sosyal medya kullanıcılarının önemli bir kısmının da bu konularla ilgili paylaşım yapan kişileri takip etmesi ya da farklı özellikleriyle tanıdıkları sosyal medya fenomenlerinin spor ve/veya siyaset konularıyla ilgili paylaşımlarına odaklanmaları da gayet doğaldır. 


\section{K. Bölükbas-A.M. Kırık Siber Zorbalık Bağlamında Twitter Fenomenleri}

Katılımcıların maruz kaldıkları elektronik içerik zorbalığı türleri ise Şekil 1'de gösterilmiştir.

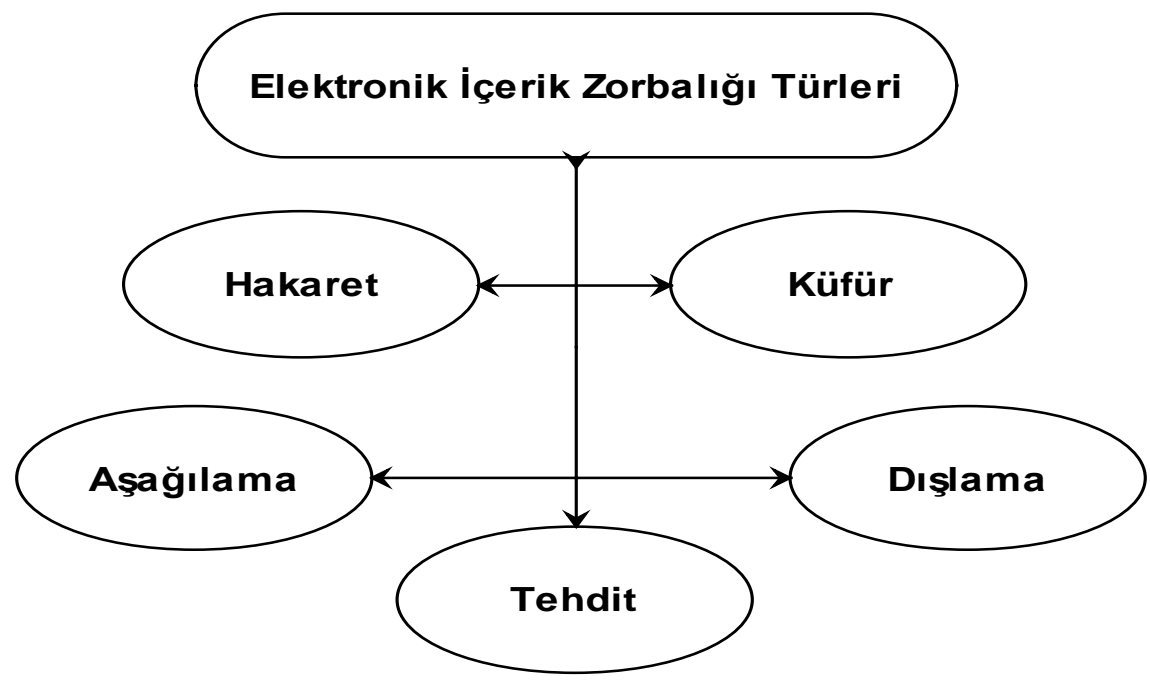

Şekil 1. Katılımcıların maruz kaldığı elektronik içerik zorbalığı türleri

Görüşülen bütün Twitter fenomenleri, paylaşımları dolayısıyla bir ya da daha fazla sayıda hakarete, küfre ve aşağılanmaya maruz kaldıklarını belirtmiştir. Sosyal medyadaki faaliyetlerinin yanı sıra gazetecilik de yapan bir katılımc1 kendisine yönelik elektronik içerik zorbalığ 1 davranışlarının ortaya çıkışını şöyle izah etmiştir:

“... Yazdığım yazıların başlığından dolayı siber zorbalığa maruz kaldım. Yazıyı okumadan sadece başlıktan ötürü saldırılar oldu, paylaşımların altında. Örneğin desteklediğim siyasi hareketin liderinin bir fotoğrafını ya da videosunu paylaştığımda siyasi olarak aşırı uçtaki bir kişi, beni tanıdığı ve normalde saygı duyduğu halde kendine hâkim olamayıp bana değilse bile bu görüsse, partiye ya da lidere saygısız ifadeler kullanabiliyor." (İrfan)

$\mathrm{Bu}$ alıntıda görüldüğü üzere sosyal medya, insanların şahit oldukları veya haklarında bilgi edindikleri ilginç olay ve durumların yanı sıra destekledikleri spor kulüpleri veya siyasi partileri ya da önemli gördükleri toplumsal olaylar hakkındaki algı, tutum, inanç ve görüşlerini paylaştıkları mecralar olarak işlev görmektedir. Bu mecralarda yayınlanan veya otantik ifadesiyle paylaşılan metin ve görsellerin kullanıcıların dikkatini çekmesi halinde, kısa zamanda çok geniş kitlelere ulaşmakta ve içeriğinin mahiyetine göre bazılarının beğenisini 
kazanırken bazı kullanıcıların da tepkilerine neden olmaktadır. Bu tepkiler bazen de burada dile getirildiği gibi küfür, hakaret, aşağılama vb. siber zorbalık davranışlarına dönüşebilmektedir.

İki katılımcı doğrudan dışlama denilebilecek siber zorbalık davranışlarıyla karşılaştıklarını belirtirken diğer katılımcılar maruz kaldıkları hakaret, küfür ve aşağılama davranışlarının önemli bir kısmının sonradan dışlamaya dönüştüğünü ifade etmiş̧tir. Doğrudan dışlama davranışına maruz kaldığını belirten Ferhat, yaptığı spor muhabirliği mesleğinin doğal bir sonucu olarak gördüğü bu durumu çok da garipsemediğini şöyle dile getirmiştir:

"Yani örneğin ben bir tweet attım. 'Dünya kupasında Türkiye'yi 3. yapan teknik direktör Şenol Güneş’tir.' diye. Mesela bununla ilgili beni şikâyet etmişler. Yanlı, Şenol Güneş'i, Beşiktaş’1 savunuyor diye. İçinde Beşiktaş yok. İçinde herhangi bir siyah beyaz bir şey yok.” (Galip)

İçeriği yukarıda verilen paylaşımı nedeniyle belirli kesimler (bu örnekte rakip futbol takımlarının taraftarları) tarafından hedef gösterildiğini ve dışlandığını belirten katılımcı, beklendik bir durum olan bu tür dışlanmaların aynı zamanda bir başka gruba (bu örnekte kendi takımı) olan aidiyet bağlarını güçlendirdiğini belirtmektedir. $\mathrm{Bu}$ tür karşılıklı etki-tepki durumlarının, dışlanmanın negatif etkilerini izale edici bir rol üstlendiğini söylemek mümkündür. Twitter'da rastlanan bir diğer dışlama/dışlanma biçimi ise topluca takibin bırakılmasıdır. Aslında doğası itibarıyla zorbalık olarak nitelendirilmemesi gereken bir davranış olan takibi bırakma, çeşitli gerekçelerle çok sayıda takipçiye sahip olmanın özendirildiği bağlamlar olan sosyal medyada, topluca gerçekleştirildiğinde bir tür zorbalık olarak görülebilmektedir. Katılımcılar, topluca takibi bırakma şeklinde ortaya çıkan siber zorbalık davranışına pek fazla maruz kalmadıklarını; çeşitli sebeplerle takibi bırakan birçok kişinin de sonradan tekrar kendilerini takip etmeye başladıklarını gözlemlediklerini ifade etmiştir.

Twitter fenomenlerinin karşılaştı̆g 1 bir diğer siber zorbalık türü ise tehdittir. Diğer zorbalık türlerine nazaran daha kapsamlı ve derin etkilere sahip olan tehdidin sıklıkla rastlanan bir davranış olmaması, sevindirici bir durumdur. Araştırma katılımcılarından üçü, Twitter paylaşımlarından dolayı tehdit aldıklarını ifade etmiştir. Katılımcılardan Sinan'ın uzun yıllardır Twitter'da olmasına ve bu mecrayı etkin bir şekilde kullanmasına rağmen şimdiye dek herhangi bir tehdit almadığını belirtmesi, ilginç bulunmuştur. Bir başka katılımcı ise Twitter'da ve diğer sosyal medya ortamlarında çoğunlukla İngilizce paylaşımlarda bulunduğunu, bu paylaşımlarda Türkiye'yi ve Türk dış politikalarını savunup destekleyen ifadelere yer verdiğini bu yüzden de özellikle terör örgütü yandaşlarının ağır tehditlerine maruz kaldığını şöyle anlatıyor: 


\section{$\underline{\text { K. Bölükbas-A.M. Kırık Siber Zorbalık Bağlamında Twitter Fenomenleri }}$}

"Özellikle uluslararası alanda yazdığım veya mentionlara girdiğimde, terör örgütü destekçileri akla hayale gelmeyecek şeyler yazıyor. Yani teröristlerden tehdit alıyorum. Küfür, hakaret, adres isteme, seni bulacağımlar..." (Abdullah)

Görüşülen Twitter fenomenlerinden biri diğeri de, bu mecra üzerinden aldığg tehditleri aşağıdaki gibi dile getiriyor:

“... Seni bulacağım, evini bulacağım, adresini bulacağım, iş adresini bulacağım, geleceğim, vuracağım, döveceğim, kıracağım, parçalayacağım diye." (Şener)

Her ne kadar bütün zorbalık türleri onlara maruz kalanlar üzerinde önemli etkiler bırakıyor olsa da dijital dünyada sergilen en aşırı zorbalık türü olan tehdit, mağdurlarının bu durumdan çok da etkilenmemeleriyle ilginç bir bulgu olarak karşımıza çıkmıştır. Katılımcılar, bu durumu "klavye delikanlılı̆̆ı" kavramıyla açıklamıştır:

“... Nefes almaktan mı s1kıldın diye bir mesaj geldi bana. Hani nasıl burada gezersin gibisinden. Ben Beşiktaş muhabiriyim. Zaten hayatım orada geçiyor. Orada da bir çay bahçesi var. Gel kardeşim dedim, geldi. Yine 17, 18 yaşında, genç bir kardeşimiz. Oturduk. Niye böyle bir şey yazdın? Dedim. Ağabey, sana kızdım. Transfer haberlerinin bir tanesi bile tutmadı falan, dedi. Beş saat konuştuk. Kalkarken selfie çekebilir miyiz? dedi. Selfie çekti, gitti. Yani klavye üzerinden insanlar çok özgür olduğunu düşünüyor. Her şeyi yapabileceklerini düşünüyor ve ne yazık ki aslında genç genç diyoruz ama yani işi olan gücü olan insanlar da ağzına ne gelirse yazabiliyor.” (Galip)

Yukarıdaki alıntıda da açıkça görüldüğü üzere sanal ortamın, herhangi bir mesajın sahibi ile onun hedefi veya alıcısı arasında meydana getirdiği görünmez duvar veya örtüler insanların bulundukları yer ve konumlarda kendilerini güvende hissetmelerine ve diledikleri küfür, hakaret ve tehditleri başkalarına kolaylıkla yönlendirmelerine zemin oluşturmaktadır. Bu da yukarıdaki örnekte olduğu gibi bazen gerçekte kast edilmeyen zorbalık davranışlarının kolaylıkla sergilenmesi ve hızla pişmanlık duyulması, bazen de fiziksel olarak gerçekleştirilemeyecek ya da gerçekleştirilmesi mümkün olmayacak bir eylemin sanal duvarlar arkasında yalnızca sözel olarak ortaya konulması şeklinde tezahür etmektedir. Buradan toplumsal yaşamda farklı türden baskılara maruz kalan bireylerin ve özellikle de ergen ve gençlerin, sanal ortamı ve sosyal medyayı kendilerini bu baskılardan uzaklaştıran özgürleştirici bir alan olarak gördükleri sonucu çıkmaktadır. Böyle bir ortamda olduklarını düşünen bireylerin gerçek yaşamda hiç karşılaşmadıkları ve muhtemelen de hiç yüz yüze gelmeyecekleri insanlara yönelik çeşitli zorbalık davranışları sergilemeleri ihtimali de artmaktadır. 


\section{Siber Zorbalığın Etkileri ve Bu Davranışlar Karşısında Sergilenen Tepkiler}

Yukarıda açıklandığı üzere katılımcıların tamamı, şu ya da bu şekilde siber zorbalığa maruz kaldıklarını belirtmiştir. Gerçek veya sanal bütün zorbalık davranışları doğal olarak muhatapları üzerinde bir etki bırakmaktadır. $\mathrm{Bu}$ saptamayı teyit eden araşıırma katılımcıları, ister istemez siber zorbalık davranışlarından psikolojik olarak etkilendiklerini ve hatta bazı durumlarda ailevi ve mesleki yaşamlarının da bu davranışlardan etkilendiğini; ancak zaman içerisinde bu tür davranışlara alıştıklarını ve üstesinden gelmeyi öğrendiklerini dile getirmişlerdir. Bir katılımcı bu ruh halini şöyle izah etmiştir:

"Eskiden saatlerce etkili olurdu, belki 24 saat sürdüğü olmuştur. Ama son yıllarda birkaç dakika içinde unutup geçiyorum çünkü üstüme almamayı öğrendim. Küfür eden kişi kendi içinde bulunduğu zavallı durumu sergiliyor. Onun için üzülüyorum. Ne yaşadı ki bunu yapacak hale geldi diyorum." (İran)

Burada görüldüğü üzere sosyal medyayı uzun süreli olarak etkili kullanan kişiler farklı şekillerde ortaya çıkan siber zorbalık davranışlarını çözümlemeyi ve onlarla baş etmeye yönelik çeşitli stratejiler geliştirmeyi öğrenmişlerdir. İrfan kod adı verilen katılımcı, maruz kaldığı siber zorbalık davranışlarıyla baş etmek için görmezden gelme, engelleme ve hukuki yollara başvuracağını bildirme aşamalarından oluşan üç kademeli bir strateji kullandığını ve izlediği bu yolun çoğunlukla işe yaradığını beyan etmiştir. Öte yandan bazı Twitter fenomenleri de siber zorbalığın kendilerini kalıcı olarak etkilediğini ve özellikle de bunu takip eden süreçteki sosyal medya paylaşımlarını bu doğrultuda yönlendirdiğini ifade etmiştir. Bu gruptaki katılımcılardan birinin beyanı şöyledir:

"Evet, bu sizin üzerinizde adeta bir mahalle baskısı olarak geri dönüyor. Bireysel konulardan çok dünya ve ülkemizi ilgilendiren toplumsal meselelerde otosansürü kendi içimde uyguluyorum. Yanlış anlaşılma ve birilerini üzmek istememe içgüdüsü diyebiliriz buna. Ayrıca bir yönden kötü bir şeyde değil bu; fütursuzluğu, içinden geçen her şeyi söylemene engele olan bir iç mekanizma." (Ahmet)

Görüldüğü üzere maruz kalınan siber zorbalık davranışları, Twitter kullanıcılarını etkileyerek kendi eylem ve paylaşımlarını gözden geçirmelerini, kontrol etmelerini ve gerektiğinde yeniden düzenlemelerini sağlayan yönlendirici bir rol oynamaktadır. Görüşülen Twitter fenomenlerinin hepsinin hem fikir olduğu bir görüş de siber zorbalık davranışları karşısında otokontrolü kaybetmeden nezaket sınırları içerisinde davranmanın, araştırmaya ve kanıtlara dayalı olarak konuşmanın her zaman işe yaradığıdır. 


\section{$\underline{\text { K. Bölükbas-A.M. Kırık Siber Zorbalık Bağlamında Twitter Fenomenleri }}$}

Görüşülen Twitter fenomenlerinin tamamı, bir birey olarak herhangi bir siber zorbalık davranışına maruz kaldıklarında hangi yasal haklara sahip olduklarını ve takip etmeleri gereken hukuki süreçlerin neler olduğunu bildiklerini dile getirmiştir. Fakat hiçbir katılımcı şimdiye kadar maruz kaldığı siber zorbalıklar karşısında yasal süreçlere başvurmayı tercih etmemiştir. Bunun sebebi ise iki türlüdür. Birincisi, katılımcıların yalnızca kendilerini ilgilendiren ve muhtemelen başkaları tarafından önemsiz olarak algılanacağını düşündükleri siber zorbalık davranışları ve suçlarını yasal süreçlere taşıyarak mahkemeleri boşuna oyalamak istememeleridir:

"Yasal haklarım ve ilgili süreçler hakkında bilgim var ama yasal yollara hiç tevessül etmedim. Birincisi uğraşmak istemiyorum. İkincisi Türkiye'de hukukun ağır işlediği inanc1, üçüncüsü de ben kavgamı yüz yüze, karş111klı, sözel bir düelloyla görmek isterim. Açıp telefonu karşımdakini sözlerimle ezmek, özür diletmek bana daha iyi geliyor.” (Şener)

Diğer sebep ise yukarıdaki alıntıda da dile getirildiği gibi Türkiye'de hukuki süreçlerin yavaş işlediği ve dolayısıyla bu yolla somut bir netice alınamayacağ yönündeki yaygın inançtır. Görüldüğü gibi söz konusu inanç, bireylerde "kendi işini kendin gör" şeklinde tanımlanacak bir anlayışın ortaya çıkmasına zemin hazırlamıştır. Öte yandan araştırma bulguları, bilişim suçları alanında uzmanlaşan hukukçuların sayısının zamanla artış gösterdiğini; bunun da siber zorbalığa maruz kalanları yasal yollara sevk edici bir işlev gördügünü ortaya koymaktadır.

\section{Sonuç}

Sosyal medyadaki siber zorbalıkları "Twitter" üzerinden değerlendirdiğimiz bu çalışmada, Twitter fenomenlerinin, paylaşımlarının içerikleri nedeniyle siber zorbalığa maruz kaldıkları görülmüştür. Alınan görüşlerin içerik analizleri; siber zorbalığın, bireyin psikolojisini ve sosyal hayatını etkilediğini destekler niteliktedir. Özellikle sosyal mecrada şifrelerin ve hesapların ele geçirilerek, "hesap üzerinden bireyin hayatına zarar vermek" amacını taşıyan elektronik zorbalık, psikolojik bir boyut kazanarak daha yıkıcı sonuçlara varmaktadır. Günümüzde kimlik gizleyebilme ile görünmezlik kazanarak, fiziksel baskı içeren akran zorbalığından ayrılan siber zorbalık, dijital mecranın önemli sorunlarından biri olmuştur. Bu kavram, çeşitli parametrelerle (cinsiyet, yaş, aile yapısı gibi) birlikte yorumlanarak ifade bulmaktadır. Buna göre yapılan görüşmelerde siber zorbalığın özellikle 16 - 18 yaş arası "ergen" olarak tanımlanan kuşakta yoğun olarak görüldüğü kanısına varılmıştır. Twitter fenomenlerine göre bu genç kuşak, klavyenin cesaretlendirici etkisiyle, ailesel ve sosyal ilişkilerinde karşılaştıkları olumsuzlukları bastırmak ve üstünlük kurmak düşüncesiyle siber zorbalığa başvurmaktadır. Bunun yanı sıra yapılan paylaşımların içeriğini beğenmeyen ya 
da kendi görüşüne uymayan bir ifadeyle karşılaşan Twitter kullanıcılarının da aynı şekilde siber zorbalığa başvurdukları ve içeriğine tepki gösterdikleri paylaşımlara hakaret, küfür, tehdit, aşağılama gibi psikolojik açıdan yıldırma amaçlı yorumlar yaptıkları ya da direkt mesaj yolu ile iletişime geçtikleri görülmüştür. Siber zorbaların bir diğer tepki yolunun ise herhangi bir iletişime geçmeden "takipten çıkmak" olduğu gözlenmiştir. Bu bağlamda görüşüne başvurduğumuz Twitter fenomenleri, toplumumuzda önemli yeri olan özellikle siyaset ve spor alanındaki siber zorbalığın iki şekli olan elektronik ve elektronik iletişim zorbalığı ile yoğun olarak karşılaştıklarını belirtmekle birlikte daha çok elektronik içerik zorbalığına maruz kaldıklarını ifade etmiş̧ir. Bu durumdan psikolojik anlamda etkilenen fenomenlerin, paylaşım içerikleri de bu sonuçlara göre şekillenmiştir. Fenomenler, paylaşımlarının içeriklerini toplumsal ve psikolojik etkilerle kısıtlama yoluna gitmişlerdir. Fenomenler, karşılaştıkları hakaret, küfür, tehdit, dışlanma gibi unsurlar nedeniyle sosyal medyada kendilerine bir otokontrol sistemi kurduklarını ve bu durumun kişinin özgürlüğünü kısıtladığını ya da "her konu hakkında konuşmaya gerek duymama" şeklinde bir etkinin ortaya çıktığını ifade etmiştir. Özellikle medya bağlamında, gazetecilerde ve basında bu sansürlerle sıkça karşılaştıklarını ifade eden fenomenler, psikolojik anlamda siber zorbalığın etkisini "yetişkin bir birey olarak" atlattıklarını ve kendilerince uyguladıkları yöntemlerle zorbalıkların önüne geçmeye çalıştıklarını belirtmişlerdir.

Twitter fenomenlerinin siber zorbalıkla ilgili yasal süreç hakkında yeterince hukuki bilgiye ve bilince sahip oldukları da görülmüştür. Aynı bilincin sosyal medyada özellikle de Twitter kullanıcılarında oluşmaya başlamasının siber zorbalığı azaltıcı bir unsur olduğunu söylemek mümkündür. Sosyal medya kullanım yaşının düşmesi nedeniyle karşılaşılabilecek sosyolojik problemleri önlemek için kullanıcıların eğitim yoluyla bilinçlendirilmesinin yanında siber zorbalıklara karşı caydırıcı yaptırımların olması bu noktada önem kazanmaktadır. Siber zorbalık konusunda bilinçlendirmenin önemine dikkat çeken fenomenler, hukuksal anlamda yaptırımların zaman almasına rağmen bir şekilde sonuca vardığını düşünmektedir. Bu noktada, bilişim suçlarında hem kadro hem de yöntem olarak uzmanlaşmaya gidildiği ve bu yöntemin hızlandırıcı sonuçlar vereceği, aynı zamanda siber zorbalıkla mücadelede önemli bir adım olacağı da vurgulanmıştır.

Siber zorbalık, sosyal medya kullanımının ve popülaritesinin artmasına paralel olarak evrensel bir nitelik kazanmıştır. Bu bağlamda siber zorbalık, sosyal medyada geçirilen zamanın sınırlarının genişlemesi ile artmış; teknolojik gelişmelerin hızla ilerlemesi ile de kolaylaşmıştır. Dolayısıyla karşılaşılan problemler, sosyolojik ve psikolojik açıdan insanları etkilemeye devam etmektedir. Bu noktada hukuksal yaptırımları minimize edecek ya da caydıracak önlemler önem kazanmaktadır. Aynı şekilde farkındalık ve toplumsal bilinç ile 


\section{$\underline{\text { K. Bölükbas-A.M. Kırık Siber Zorbalık Bağlamında Twitter Fenomenleri }}$}

siber zorbalıkla mücadelede önemli bir yol kat edileceği de açıktır. İnternet kullanımında adab-1 muaşeret ve yasal yaptırımların gözetiminin, siber zorbalı̆̆ 1 azaltıcı bir etkiye sahip olacağını söylemek mümkündür. Bu noktada, arada elektronik bir araç olsa da birey, karşısındakinin de bir birey olduğunun farkına varabilecek ve davranışlarını bu doğrultuda şekillendirebilecektir. Özellikle son yıllarda sosyal medya platformlarının izlediği bir takım politikalarla, adab-1 muaşeret ve yasal yaptırım kuralları gözetilmeye çalışılmaktadır. Troll olarak nitelendirilen kimliksiz hesaplardan siber zorbalık yapanlara karşı sosyal medya platformları "gerçek isim politikası" izlemektedir. Bu durum "nick name" olarak adlandırılan takma isimli hesapların azaltılması açısından önemli bir adımdır. Twitter başta olmak üzere diğer sosyal medya platformlarının kullandığı "mavi tik" uygulamasını da bu politikaların bir devamı gibi düşünmek mümkündür. Sonuç olarak bireyler internet başındayken, kendilerine davranılmasını istedikleri şekilde karşı tarafı muhatap aldıklarında, siber zorbalığın yıkıcı etkileri de bir anlamda ortadan kalkacaktır.

\section{KAYNAKÇA}

Aksaray, Semra (2011), “Siber Zorbalık”, Ç.Ü. Sosyal Bilimler Enstitüsü Dergisi, 20 (2), ss.405-432.

Bulmer, Donald ve DiMauro, Vanessa (2009), “Executive Summary from the Society for New Communications Research Study: The New Symbiosis of Professional Networks: Social Media's Impact on Business and Decision-Making”, Journal of New Communications Research, 4(2), ss.93-100.

Çelik, Tolga ve Tekin, Yeşim (2015), "Sosyal Medyanın Bireyler Üzerindeki Olumsuz Etkilerine İlişkin Bir Örnek: Siber Zorbalık.” The Journal Of Academic Social Science Studies, Say1 36, ss.343-355.

Dijilopedi (2019), "2019 Türkiye İnternet Kullanımı ve Sosyal Medya İstatistikleri." https://ijilopedi.com/2019-turkiye-internet-kullanimve-sosyal-medya-istatistikleri/, Erişim Tarihi: 30.06.2020.

Dijilopedi (2020), “2020 Türkiye İnternet Kullanımı ve Sosyal Medya İstatistikleri." https://dijilopedi.com/2020-turkiye-internet-kullanimive-sosyal-medya-istatistikleri, Erişim Tarihi: 08.06.2020.

Dokuz8 Haber, (2019), "Verilerle Dünyada İnternet ve Sosyal Medya Kullanımı.” https://dokuz8haber.net/veri-haberciligi/verilerle-dunyadainternet-ve-sosyal-medya-kullanimi-turkiye-instagram-kullanimindabirinci-sirada/, Erişim Tarihi: 31.06.2020. 
Dumanlı Kürkçü, Duygu (2017), “Twitter Kullanıcılarının Cinsel İstismar Olaylarına Verdikleri Tepkiler: Kullanıcılarının Profili ve İçerik Analizi”, Pamukkale Üniversitesi Sosyal Bilimler Enstitüsü Dergisi, Say1: 30, ss.53-65.

Erbaş, Emre ve Şahin Perçin, Nilüfer (2017), “Ahlaki Çözülme (Moral Dısengagement) Ölçeği Türkçe Geçerlemesi ve Kişi-Çevre Uyumu İlişkisi”, AİBÜ Sosyal Bilimler Enstitüsü Dergisi, 17 (1), ss.177-190.

Erdur-Baker, Özgür (2013), “Görünümleri ve İlgili Değişkenleriyle Siber Zorba ve Siber Kurbanlar.” 1. Türkiye Çocuk Ve Medya Kongresi Bildiriler Kitab1, ss.277-295.

Gil de Zúñiga, Homero, Barnidge, Matthew ve Diehl, Trevor (2018), “Political Persuasion on Social Media: A Moderated Moderation Model of Political Discussion Disagreement and Civil Reasoning." The Information Society, 34(5), ss.302-315

Hinduja, Sameer ve Patchin, Justin W. (2010), "Bullying, Cyberbullying, and Suicide.” Archives of suicide research, 14(3), ss.206-221.

İsmayılzada, Laman (2017), “Sanal Dünyada Sanal Dönüşüm”, Electronic Journal Of New Media. 1 (3), ss.227-235.

Kılıçer, Kerem, Özeke, Vildan ve Çoklar, Ahmet Naci (2018), “Sosyal Medya Kullanıcılarına Ait Siber Davranışların İnsani Değerler Bağlamında İncelenmesi”, Dumlupınar Üniversitesi, Sosyal Bilimler Dergisi. Sayı 56, ss.19-39.

Kırık, Ali Murat, Çetinkaya, Ahmet ve Şahin, Özgür Erkut (2014), “A Research on Social and Political Use of Social Media in Turkey”, International Journal of Science Culture and Sport (IntJSCS), 2(4), ss.49-60.

Köseoğlu, Özgür (2006), "Bilgi İletişim Teknolojilerinin Pazarlamaya Etkisi.” Bilgi İletişim Teknolojileri ve Yansımaları (ed. Beril Akıncı Vural), 1.Baskı, Nobel Yayın Dağıtım, Ankara.

Kuşay, Yeliz (2010), "Sosyal Medyanın Gücü ve Uygulama Örnekleri - İkinci Medya Çağında İnternet.” (Derl. Filiz Aydoğan, Ayşen Akyüz), 1.Bask1, Alfa Yayınları, İstanbul.

Medya Akademi. (2020), "2020 Sosyal Medya Kullanıcı Sayıları." https://medyaakademi.com.tr/2020/02/03/2020-sosyal-medya-kullanicisayilari/, Erişim Tarihi: 30.06 .2020 
$\underline{\text { K. Bölükbas-A.M. Kırık Siber Zorbalık Bağlamında Twitter Fenomenleri }}$

Milli Eğitim Bakanlığı (MEB). (t.y.). "Siber Zorbalık, Bilişim Suçları ve Bunlarla Mücadele Etme”, http://bulancakmehmetakifersoy.meb.k12.tr/meb iys dosyalar/28/03/97 5183/dosyalar/2017_11/14192117_syberzorbalık.pdf,Erişim Tarihi: 09.07.2018.

Özdemir, Murat ve Akar, Filiz (2011), "Lise Öğrencilerinin Siber Zorbalığa İlişskin Görüşlerinin Bazı Değişkenler Bakımından İncelenmesi”, Kuram ve Uygulamada Eğitim Yönetimi, 17 (4), ss.605-626.

Özer Baltac1, Halime (2016), "İletişim Becerileri ve Empatik Eğilim Arasındaki İlişskinin $X$ ve $Y$ Kuşaklarına Göre Farklılıklarının İncelenmesi ve Bir Uygulama”, Yüksek Lisans Tezi, Bahçeşehir Üniversitesi, Sosyal Bilimler Enstitüsü, İstanbul.

Patton, Michael Quinn (2014), “Nitel Araştırma ve Değerlendirme Yöntemleri”, (Çev. Ed. M. Bütün ve S. B. Demir). Pegem Akademi Yayınları, Ankara.

Peker, Adem, Eroğlu, Yüksel ve Ada, Şükrü (2012). “Ergenlerde Siber Zorbalığın ve Mağduriyetin Yordayıcılarının İncelenmesi”, Abant İzzet Baysal Üniversitesi Eğitim Fakültesi Dergisi. 12(2), ss.185-206.

Sabuncuoğlu, Ayda ve Gülay, Göker (2014), “Sosyal Medyadaki Yeni Kanaat Önderlerinin Birer Reklam Aracı Olarak Kullanımı: Twitter Fenomenleri Üzerine Bir Araştırma”, Gazi Üniversitesi İletişim Fakültesi, Süreli Elektronik Dergi, İletişim Kuram Ve Araştırma Dergisi. Sayı 38, ss.1-24.

Sart, Gamze (2015). “Fenomenoloji ve Yorumlayıcı Fenomenolojik Analiz. Nitel Araştırma: Yöntem, Teknik, Analiz ve Yaklaşımlar”, F. N. Seggie ve Y. Bayyurt (Ed.) Anı Yayıncılık, Ankara.

Serin, Hüseyin (2012). "Ergenlerde Siber Zorbalık / Siber Mağduriyet Yaşantıları ve Bu Davranışlara İlişkin Öğretmen ve Eğitim Yöneticilerinin Görüşleri”, Doktora Tezi, İstanbul Üniversitesi, Sosyal Bilimler Enstitüsü, Eğitim Bilimleri Anabilim Dalı, İstanbul.

Taştekin, Ezgi ve Bayhan, Pınar (2018), "Ergenler Arasındaki Siber Zorbalığın ve Mağduriyetin İncelenmesi”, Online Journal of Technology Addiction\&Cyberbullying, 2018, 5(2), ss.21-45.

Tuncer, Murat ve Dikmen, Melih (2016), "Sosyal Ağlarda Bekleyen Yeni Tehlike: Siber Zorbalık" Frrat Üniversitesi, 4. International 
Instructional Technologies\&Teacher Education Symposium, ss.94-104.

Türkiye İstatistik Kurumu (2019), "Hane Halkı Bilişim Teknolojileri Kullanım

Araştırması." http://www.tuik.gov.tr/PreHaberBultenleri.do?id=30574, Erişim Tarihi: 04.06.2018.

Vandebosch, Heidi ve Van Cleemput, Katrien (2009), “Cyberbullying Among Youngsters: Profiles of Bullies and Victims”, New media \& society, 11(8), ss.1349-1371.

Willard, Nancy E. (2007), "Cyberbullying and Cyberthreats: Responding to the Challenge of Online Social Aggression, Threats, and Distress." Research press, Research press.

Yaylagül, Şinasi (2017), "Sosyal Medya Fenomenlerine Bağlanmışlığın Belirlenmesi: Yükseköğretim Öğrencileri Üzerine Bir Uygulama.” Adnan Menderes Üniversitesi, Sosyal Bilimler Enstitüsü Dergisi. 4 (3), ss.219-235.

Yiğit, Mehmet Fatih ve Seferoğlu, Süleyman Sadi (2017), "Siber Zorbalıkla İlişsili Faktörler ve Olası Çözüm Önerileri Üzerine Bir İnceleme.” Online Journal Of Technology Addiction\&Cyberbullying, 4(2), ss.13-49. 